\title{
Literasi Media Melalui Kajian Linguistik Fungsional di Indonesia
}

\author{
Wulan Rahmatunisa \\ Universitas Kuningan \\ wulan.rahmatunisa@uniku.ac.id
}

\begin{abstract}
ABSTRAK
Gempuran hoax atau berita bohong menjadi semakin menghawatirkan. Penggunaan sosial media yang menjadi salah satu arena penyebaran hoax harus mendapat perhatian utama khususnya bagi generasi $\mathrm{Z}$ yang merupakan konsumen mayoritas dari jejaring tersebut. Pada makalah ini akan dipaparkan mengenai bagaimana peranan literasi media melalui kajian linguistik fungsional menjadi senjata terhadap serangan berita bohong, yang diterapkan dalam ranah pendidikan di Indonesia. Literasi media merupakan sarana untuk menjadikan kita pembaca yang kritis dan tidak langsung terprovokasi oleh isu yang media sajikan (Cope, 2002). Sebagai bagian tak terpisahkan dari esensi Systemic Functional Linguistics atau tata bahasa fungsional, literasi media mengajak kita untuk faham akan bagaimana sebuah teks memiliki multidimensi dalam pengkonstruksian makna (Halliday dan Matthiessen, 2004). Oleh karena itu, sudah saatnya linguistik fungsional digalakan sebagai senjata ampuh anti hoax dalam dunia pendidikan di Indonesia.
\end{abstract}

Kata kunci: tata bahasa fungsional, literasi media, generasi z, hoax

\section{PENDAHULUAN}

Tata bahasa fungsional atau Systemic Functional Linguistics (SFL) pada dasarnya merujuk pada tiga hal, seperti yang dikemukakan oleh Halliday dan Hasan (1985), bahwa "systemic" berarti makna yang dikonstruksi sebagai pilihan (meaning as choice); "functional" mengindikasikan bahwa bahasa yang digunakan manusia memainkan fungsi dan peran-peran tertentu dan berkontribusi besar terhadap bagaimana manusia memposisikan dirinya terhadap sebuah diskursus yang akan dan telah diproduksi; dan "grammar" merupakan deskripsi mengenai bahasa manusia, yang dikaitkan dengan sebuah nosi mengenai bagaimana struktur internal bahasa memberi pengaruh terhadap sistem makna. Dengan kata lain SFL merupakan teori bahasa yang menekankan pada nosi bahwa setiap penggunaan bahasa digramatikalisasi dengan cara-cara tertentu sehingga sebuah sistem makna lahir atas sebuah pilihan (dan bisa ditelisik secara ilmiah), dan bukan merupakan sesuatu yang lahir begitu saja tanpa sebuah pertimbangan tertentu. Deskripsi bahasa beraliran fungsional ini mengungkap pertanyaan dasar apa yang bisa manusia lakukan dengan bahasa yang mereka miliki; fungsi dan peran khusus apa yang direalisasikan dari bahasa; dan bagaimana sebuah tata 
bahasa mengkonstruksi dan merealisasikan makna dalam diskursus sehari-hari (Bumela, 2013).

Seperti yang ditegaskan Halliday $(2004 ; 1994 ; 1985)$, teks, yang dipersepsi sebagai bentuk nyata dari apa yang kita dengar-ucap dan segala yang kita tulis, merupakan sumber data yang tidak akan pernah habis untuk digali. Ini disebabkan karena sejarah peradaban manusia selalu direkam, dipertanyakan, dipertentangkan, dimediasi, dan diabadikan lewat teks. Halliday juga mengungkapkan bahwa sebuah teks memiliki banyak sisi sehingga ia bisa didekati dengan perspektif yang beragam. Namun, Halliday berpendapat bahwa ada terdapat dua perspektif dasar untuk melihat keberadaan sebuah teks: teks sebagai sebuah objek alamiah dan teks sebagai instrumen yang bisa digunakan untuk mencari tahu lebih dalam apa yang tersimpan di balik sebuah teks, misalnya, ideologi, jejak kultural, dan artefak budaya tertentu.

Halliday $(2004 ; 1994 ; 1985)$ mengatakan bahwa apabila sebuah teks dipersepsi sebagai sebuah objek, maka grammarian bisa mengajukan pertanyaan berikut: (1) mengapa teks tertentu memaknai dirinya dengan cara-cara tertentu? dan (2) mengapa jenis teks tertentu mesti dihargai, dinilai, dipersepsi sebagaimana mestinya? Sedangkan, apabila kita melihat teks sebagai sebuah instrumen, maka pertanyaan paling relevan yang bisa diajukan adalah sistem bahasa macam apakah - lisan atau tertulis - yang diungkap oleh teks tersebut. Kedua pendekatan tersebut, menurut Halliday, tidak usah menjadi dikotomi using karena justru keduanya harus disalinghadapkan dan dikombinasikan agar sistem bahasa - yang biasa kita sebut grammar - dapat dideskripsikan. Dengan adanya deskripsi tertentu mengenai grammar, kita memiliki akses luas untuk mengeksplorasi sebuah karunia termegah yang kita miliki sebagai manusia: bahasa.

Sejak dahulu para linguis - termasuk para grammarian, psikolog, antropolog, sosiolog - menjadikan bahasa sebagai sebuah entitas ilmiah yang terus menerus dikaji dan diteliti dalam berbagai perspektif. Chomsky mendekati bahasa lewat pendekatan kognitif generative dan Halliday mendekati bahasa dari fungsi sosial yang dimainkan bahasa. Generative grammar menitikberatkan pada aspek internal bahasa sebagai sebuah sistem mental (Bumela, 2013). Data yang dimunculkan adalah dalam bentuk apa bahasa tertentu direalisasikan oleh seorang individu, dan fenomena ini bisa digeneralisasi (dan diuniversalisasi) menjadi teori bahasa baru. Functional grammar yang digagas Halliday, sebaliknya, menitikberatkan pada realisasi bahasa dalam dimensi sosialnya yang luas. Kondisi sosial-kultural tertentu akan melahirkan jenis-jenis teks - yang kemudian dipersepsi sebagai diskursus - yang beragam.

Dalam konteks Anglo-Saxon, misalnya, sebuah teks naratif memiliki struktur generik yang terdiri dari orientation, complication, resolution, dan coda. Di bagian orientation, misalnya, fitur khas yang muncul adalah "Once upon a 
time...", yang menandakan secara spesifik bahwa teks yang diproduksi adalah naratif, bukan deskriptif, prosedural, atau jenis teks yang lain. Jenis kata kerja (process type) yang biasanya banyak muncul dalam naratif teks adalah material process, kata kerja yang merepresentasikan kegiatan bernuansa fisik seperti makan, minum, berlari, menulis, dll. Selain itu, secara semantic verba yang digunakan dalam teks naratif (dan teks recount) harus berupa kata kerja kedua (verb two), yang mengindikasikan bahwa semua kejadian dalam teks tersebut terjadi di masa lalu. Sebaliknya, jenis verba pertama (verb one) dalam bentuk present tense akan mendominasi teks ber-genre deskriptif dan procedural. Khusus untuk teks procedural, jenis klausa yang dimunculkan harus dalam bentuk imperative, bukan declarative. Ini terkait dengan sifat alamiah teks tersebut yang bernuansa menginstruksikan sesuatu.

Dari penjelasan singkat di atas, benang merah yang ditarik yaitu bahwa grammar direalisasikan dengan cara yang berbeda untuk jenis teks yang berbeda. Dari sinilah titik penghubung antara grammar dan teks terbangun. Pemahaman ini merupakan pijakan dasar untuk memahami dimensi teoretis dari sebuah deskripsi bahasa berlabel tata bahasa fungsional, yang sayang masih dipertentangkan dan dipertanyakan secara parsial oleh banyak pihak termasuk para guru (dan dosen) yang sehari-hari bertugas mengajarkan jenis-jenis teks yang beragam kepada (maha) siswanya.

\section{PEMBAHASAN}

\section{Tata bahasa fungsional dan literasi}

Tata bahasa fungsional menangkap dan menegaskan ulang bahwa bahasa memainkan peranan yang jauh lebih penting daripada yang kita bayangkan selama ini. Lewat teori metafungsi, misalnya, tata bahasa fungsional melihat bahwa teks - semua bentuk penggunaan bahasa - merupakan representasi pengalaman manusia (ideasional). Sebuah pengalaman dan kejadian yang sama cenderung direpresentasikan secara berbeda oleh individu yang berbeda (Derewianka, 1990). Ini terkait dengan aspek interpersonal individu tersebut dengan apa yang dia alami dan dengan siapa dia berinterkasi. Pada titik inilah makna interpersonal memainkan perannya.

Pada dimensi lain - moda komunikasi sebuah teks - menampilkan wajah makna ideasional dan interpersonal dengan cara yang berbeda. Bentuk dasar dari sebuah teks - lisan dan tertulis - memberi warna berbeda terhadap bagaimana sekumpulan informasi disampaikan (Martin, 1985). Kepekaan dan kesadaran mengenai moda tekstual ini menjadi sangat krusial dalam dunia akademik khusunya. Tidak lain tidak bukan ini disebabkan karena dunia akademik memberi penekanan dan apresiasi yang sangat besar terhadap karya tulis, yang semestinya tidak dikonstruksi sebagai diskursus lisan. 
Selain itu, aspek kohesi menjadi pertimbangan yang sangat serius untuk disematkan pada diskurus tertulis. Setelah makna ideasional dan interpersonal dipetakan maka tugas terberat seorang pengguna bahasa yang cerdas adalah memastikan bahwa teks yang ia produksi dapat disampaikan dengan moda yang tepat sesuai dengan konteks yang menyelimutinya. Keteraturan dan keberaturan gagasan yang diusung pun harus diatur sedemikan rupa dengan menggunakan "cohesive devices" yang tepat (Eggins, 2004). Tujuannya tidak lain untuk menegaskan bahwa sebuah teks mampu mencapai titik "ekuilibrium", titik di mana sebuah teks dikonstruksi sesuai dengan fitrah genre-nya dan tujuan sosial (social purpose) dari teks tersebut dapat direalisasikan.

Lewat pembahasan mengenai metafungsi, diharapkan bahwa para pengguna bahasa - dalam konteks ini merujuk pada (maha) guru dan (maha) siswa - dapat memaksimalkan potensi makna yang secara inheren dapat digali dari semua jenis teks. Menggali potensi makna semacam ini tentu saja membutuhkan keahllian membaca yang canggih alias tidak bergerak di area pemahaman literal belaka, tapi harus bergerak ke pemahaman tingkat kritis dan keratif.

Keahlian membaca kritis pada tahap ini nampaknya merupakan 'prasyarat' informal bagi semua pengguna bahasa di dunia yang sudah membekali dirinya dengan literasi dasar. Dengan adanya perkembangan teknologi yang cepat dan masif, kelahiran teks-teks dan tafsir-tafsir baru pun bermunculan di layar laptop dan telepon genggam kita dengan jumlah yang tak terhitung. Berita mengenai suatu kejadian di pelosok dunia kini bisa mencapai genggaman kita pada hari bahkan jam yang sama. Sungguh kecepatan informasi ini membuat dunia berputar begitu cepat. Bahkan sangat cepat jauh melebihi kilatan petir ketika badai menghantam.

Saking banyaknya informasi yang melanda tiap detik kehidupan kita, lahirlah sebuah kebingungan. Kebingungan yang lahir bukan karena kita tidak punya pilihan tapi justru disebabkan karena teralu banyak pilihan yang tersedia bagi kita. Sebagai guru pun terkadang kita bingung memilih jenis teks primer dan sekunder yang pas dengan kebutuhan siswa dan sesuai dengan tuntutan kurikulum. Kebingungan ini akan menjadi semacam malpraktik pengajaran apabila sang (maha) guru tidak memahami dengan benar mengenai jenis teks dan bagaimana potensi makna dalam teks tersebut dikonstruksi, diinterpretasi, dan diproduksi ulang oleh para (maha) siswanya.

Pada konteks semacam inilah tata bahasa fungsional menawarkan diri untuk diadopsi khususnya oleh dunia pendidikan bahasa. Dengan mengadopsi tata bahasa fungsional sebagai pisau bedah, seorang (maha) guru dapat berbicara banyak mengenai teks yang ia bahas dengan para (maha) siswanya. Pembahasan ideal mengenai teks tentu saja tidak hanya dimulai dengan fitur superfisial teks tersebut saja (judul isi, kesimpulan), tapi juga harus mengungkap bagaimana 
genre teks tersebut merealisasikan tujuan sosial yang diusung lewat teks tersebut. Dan ini hanya dimungkinkan apabila sang (maha) guru bisa menjelaskan dengan baik bagaimana ketiga sistem makna - ideasional, interpersonal, dan tekstual tersebut dikonstruksi dalam teks tersebut.

\section{Literasi media dalam dunia pendidikan}

Dalam kurikulum nasional mata pelajaran bahasa Inggris untuk tingkat sekolah menengah (SMP-SMA), telah dinyatakan dengan jelas bahwa pengajaran bahasa Inggris saat ini difokuskan pada pengembangan literasi fungsional untuk tingkat SMP/MTs dan literasi informasional untuk tingkat SMA/MA. Literasi fungsional mencakup kemampuan menggunakan bahasa (ibu dan asing) untuk pemenuhan kebutuhan sehari-hari, sedangkan literasi informasional mencakup kemampuan baca-tulis untuk mengakses ilmu pengetahuan (Bumela, 2013). Dua jenis literasi ini merupakan bagian dari jenis literasi yang dikembangkan oleh Wallace (2003) dan diafirmasi oleh Alwasilah (2001). Dua jenis literasi lain yang diteorikan oleh Wallace mencakup literasi performatif, yang merupakan kemampuan membaca-menulis dasar pada level sekolah dasar dan literasi epistemik yang mencakup kemampuan untuk mentransformasikan pengetahuan pada tingkat perguruan tinggi.

Keempat jenis literasi yang dikemukakan oleh Wallace merupakan jenjang keahlian literasi yang diakuisisi dan harus dikembangkan dengan runut. Kegagalan mahasiwa dalam mentransformasikan pengetahuan yang dimiliknya bisa jadi merupakan efek akhir dari tidak berkembangnya tiga literasi sebelumnya (performatif, fungsional, dan informational). Namun, banyak pihak yang tidak menyadari bahwa pengembangan literasi siswa merupakan proses panjang yang tidak akan pernah berakhir.

Pengalaman membaca-menulis di sekolah semestinya menjadi menu utama pengajaran bahasa (asing) karena siswa (dan gurunya) harus disadarkan kembali bahwa belajar bahasa (asing) ditujukan untuk mengembangkan kemampuan komunikatif. Kegiatan berkomunikasi dasar pada umumnya direalisasikan lewat dua moda: lisan dan tulisan, dan merupakan tugas guru untuk memastikan bahwa para siswanya mampu berbicara dan menulis dalam konteks yang berterima (Bumela, 2012).

Anderson dan Anderson (1997) mencatat bahwa ada dua kategori besar yang wajib untuk diintroduksi kepada siswa selama masa sekolah: literary (kesusastraan) dan faktual. Teks jenis pertama sebenarnya bukan yang sesuatu yang asing bagi kita semua karena jenis teks tersebut berdenyut dalam keseharian kita. Jenis-jenis teks bernyawa sastra yang biasa dipresentasikan ke hadapan kita mencakup naratif, puisi, dan drama. Tiga jenis teks ini diwujudkan lagi dalam bentuk-bentuk lain. Sebut saja film dan skrip film, cerita tentang fairy, novel, 
lirik lagu, soap opera (termasuk sinetron), pertunjukan drama, pertunjukan wayang (puppet show) dan wayang orang, dsb. Dengan adanya perkembangan teknologi mutakhir di akhir abad 21 ini justru kita lebih mudah mengakses jenis teks sastra dalam berbagai media: film, video, $\mathrm{CD}$, acara televisi, dsb. Kemudahan ini semestinya memudahkan para (maha) guru untuk mengeksplorasi pengalaman tekstual para (maha) siswanya. Pada kenyataannya, tetap saja upaya untuk mengoptimalkan semua perangkat pengetahuan dan pengalaman siswa tidak semudah membalikkan telapak tangan.

Berdasarkan pengalaman penulis selama ini, pembahasan guru tentang naratif teks selalu berujung pada pertanyaan guru yang berpusat pada struktur generik teks, bukan pada pertanyaan apakah teks yang ditulis para (maha) siswa telah merealisasikan tujuan sosial (social purpose) dari teks tersebut. Pertanyaan seputar bagaimana makna direalisasikan lewat tata bahasa pun hilang dari jangkauan. Pemandangan ini mengindikasikan bahwa ada kecenderungan bahwa teks naratif dieksplorasi (diajarkan, dituliskan, dan dievaluasi) secara tidak tepat.

Jenis teks kedua - faktual - juga kemungkinan besar mengalami nasib serupa. Ketika teks faktual ini dieksplorasi di dalam kelas, nampakanya tingkat kesulitan siswa mengalami eskalasi yang tak terkira. Ini disebabkan karena jenis teks faktual memiliki fitur yang lebih 'menantang' untuk ditaklukkan sekalipun para (maha) siswa telah sering bersentuhan dengan beberapa jenis teks faktual.

Terdapat tujuh jenis teks faktual yang dikemukakn oleh Anderson dan Anderson (1997): recount, explanation, discussion, information report, exposition, procedure, response. Pada dasarnya ketujuh jenis teks faktual ini bermura pada satu tujuan sosial: untuk menghadirkan informasi dan gagasan ke khalayak luas dan untuk menunjukkan, memberitahukan, serta membujuk audiens tertentu untuk melakukan sesuatu. Di sinilah salah satu letak kesulitan yang menghadang para (maha) siswa. Dalam konteks persekolahan para (maha) siswa dituntut untuk mampu mengkomunikasikan gagasannya lewat cara-cara tertentu agar teks yang ia produksi memiliki peran sosial yang nyata. Terdengar masuk akal apabila seorang (maha) siwa tidak akan mampu meyakinkan diri orang lain selama ia tidak mampu meyakinkan dirinya sendiri. Di titik inilah pendidikan bahasa harus mewujud nyata: menjembatani segala kelebihan dan kekurangan siwa dengan semua kemungkinan kurikuler yang ada.

Pada dasarnya jenis teks faktual juga sering kita jumpai dalam diskursus sehari-hari. Iklan, pengumuman, website di internet, debat, resep masakan, laporan (report), dan instruksi merupakan jenis faktual yang biasa kita jumpai dari hari ke hari. Namun, nampaknya kita tidak menyadari bahwa ada perbedaan besar antara bagaimana teks sastra dan faktual itu direalisasikan. Ketika para siswa telah mampu menulis teks, tetap saja ada sesuatu yang hilang: konteks. 
Perlu dicermati bahwa konteks merupakan suatu entitas yang utuh. Ia merupakan kombinasi dari seperangkat pengetahuan dan pengalaman sang penulis dengan segala latar belakangnya dan seperangkat pengetahuan dan pengalaman pembaca dengan segala pengalamannya. Dengan kata lain, konteks mencakup bukan hanya yang ada di dalam teks, tapi juga apa yang ada di dalam diri pembaca teks tersebut. Tidak heran apabila Lehtonen (2000) menegaskan bahwa konteks merupakan "fellow-text", atau teks-teks lain yang menyertai kelahiran teks lain. Fakta ini juga mengindikasikan bahwa sebuah teks akan selalu terkait dengan teks-teks serupa yang relevan. Unsur inilah yang kemudian disebut sebagai intertekstualitas, yang eksistensinya harus dikenali dan dimunculkan dalam proses kreasi teks-teks baru.

Pada tahap ini, maka jelaslah bahwa konteks merupakan aktor internal dan eksternal yang melingkupi sebuah teks, yang melahirkan fakta bahwa ada sebuah hubungan yang 'innate' antara penulis (author) dengan teks yang ia kreasikan dan juga antara pembaca dengan teks yang ia baca. Upaya untuk memunculkan konteks, menurut Lehtonen (2000), bisa dilakukan denga cara melacak apa yang mewujud dalam teks. Ada delapan elemen dalam teks yang harus mendapat perhatian:

1. Substance: dimensi fisik dari sebuah teks.

2. Musik dan gambar

3. Paralanguage: kualitas suara, gesture, sentuhan dan ekspresi wajah, ukuran huruf, dan jenis warna yang digunakan dalam teks.

4. Situation: property dan hubungan antara objek dan manusia yang berada dalam lingkup teks tersebut.

5. Co-text: teks-teks lain relevan yang bisa digunakan untuk penunjang analisis dan berada pada diskursus yang sama.

6. Intertext: teks yang dipersepsi oleh participant lain sebagai teks yang berada di luar jangkauan diskursus yang sedang dibahas, yang berpengaruh terhadap bagaimana mereka menafsirkan sebuah teks.

7. Participants: semua yang terhubung dengan intensi (niat) dan interpretasi partisipan dalam teks (pembaca dan penulis). Juga termasuk di dalamnya seperangkat pengetahuan dan kepercayaan, perilaku interpersonal, afiliasi dan segala bentuk perasaan.

8. Function: apa yang diniatkan oleh sang penulis dan apa yang diniatkan oleh sang pembaca.

Kedelapan elemen konteks tersebut merupakan sesuatu yang wajib dilihat oleh para analis diskursus. Ini disebabkan karena sebuah diskursus merupakan kombinasi alamiah antara teks dan konteks. Memang pada titik tertentu bisa jadi tidak semua elemen konteks akan muncul dalam sebuah teks, namun tugas seorang analis diskurus - termasuk di dalamnya para (maha) guru dan (maha) 
siswa yang bergulat dengan dunia genre dan pengajarannya - untuk menguak konteks apa saja yang menemani teks tertentu sebelum akhirnya keberadaan mereka dimaknai sebagai suatu entitas yang memberi atribut penting terhadap sebuah teks.

Ada sebuah pertanyaan yang selama ini menggelayut di benak penulis: selama ini apakah para (maha) guru dan (maha) siswa telah memperlakukan teks sebagai sebuah diskursus sehingga aspek komunikatif dari sebuah teks benar-benar dihadirkan di dalam dan di luar kelas? Berdasarkan beberapa kali observasi yang telah dilakukan selama tiga tahun terakhir, ditemukan fakta bahwa sebuah teks naratif, misalnya, menjadi kering makna karena ia diproduksi siswa bukan dalam konteks untuk menghibur pembaca, tapi sekedar menulis untuk memenuhi tugas guru. Banyak di antara (maha) siswa tidak bisa menjawab pertanyaan seputar bagaimana sebuah teks naratif yang telah mereka tulis sendiri merealisasikan tujuan sosial teks tersebut. Untuk menjawab pertanyaan semacam ini tentu saja dieprlukan pengetahuan dasar yang kuat pada struktur generik dan fitur lexicogrammatikal sebuah teks naratif. Pemahaman paripurna mengenai kedua hal ini merupakan sesuatu yang waib dimiliki oleh para (maha) guru dan (maha) siswa yang bergerak dalam dunia pendidikan bahasa. Kegiatan membaca-menulis yang menjadi inti dari pendidikan merupakan sebuah proses sosial yang rumit, sehingga semua kegiatan yang berhubungan dengan teks bisa dipastikan selalu terkait dengan konteks. Oleh karena itu, konteks merupakan roh dari sebuh teks, yang tidak boleh dihindari oleh pembaca. Ketika seorang pembaca telah mampu mengawinkan eksistensi sebuah teks dan konteks, maka barulah ia bisa memainkan peran sosialnya untuk sebuah proses negosiasi makna.

\section{SIMPULAN}

Berdasarkan pemaparan di atas, dapat disimpulkan bahwa linguistik fungsional sebaiknya menjadi pijakan dasar bagi pendidik dalam mensukseskan literasi media. Pemahaman mengenai sebuah teks bisa dicapai dengan baik apabila pembaca mengerti akan entitas teks yang dikonstruksi dengan pola-pola yang dipelajari melalui kajian linguistik fungsional. Kompleksitas yang terlihat dari bagaimana sebuah teks dianalisis tidak dimaksudkan untuk melahirkan kesan "ngeri" dan menakutkan, tapi justru dengan kompleksitas yang dihadirkan tersebut mengindikasikan sebuah fakta bahwa sebagai entitas yang merekam setiap jejak pengalaman kita, tata bahasa telah menjalankan tugasnya dengan baik. Pengalaman sesederhana apapun tetap merupakan sebuah kompleksitas besar yang justru direkam dan disederhanakan oleh tata bahasa. 


\section{DAFTAR PUSTAKA}

Alwasilah, A.C. (2001). Language, culture, and education: A portrait of contemporary Indonesia. Bandung: Bahasa \& Seni Press.

Anderson, M., \& Anderson, K. (1997). Text types in English. South Yarra: Macmillan Education Australia.

Bumela, L. (2012). The metafunctions revealed: EFL learners' experiences in making sense of the texts. CONAPLIN Journal, Second Volume 1.2, 60-72.

Bumela, L. (2013). Mengeksplorasi tata bahasa fungsional. Cirebon: IAIN Syeh Nurjati Press.

Cope, N. (2002). Linking critical literacy and media literacy in an academic preparation program. Prospect, Vol. XVII, No. 2, April, 2002.

Derewianka, B. (1990). Exploring how text work. Sydney: Primary English Teaching Association.

Eggins, S. (2004). An introduction to systemic functional linguistics $\left(2^{\text {nd }}\right.$ ed.). London: Continuum International publishing group.

Halliday , M. A. K., \& Hasan, R. (1985). Language, context, and text: Aspects of language in a social-semiotic perspective. Victoria: Deakin University.

Halliday, M.A.K. (1994). An introduction to functional grammar (2 ${ }^{\text {nd }}$ ed). London: Edward Arnold.

Halliday, M.A.K., \& Matthiessen, C. (2004). An introduction to functional grammar ( $3^{\text {rd }}$ ed.). London: Hodder Arnold.

Lehtonen, M. (2000). The cultural analysis of text. London: Sage Publication Ltd.

Martin, J.R. (1985). Factual writing: Exploring and challenging social reality. Melbourne: Deakin University Press.

Wallace, C. (2003). Critical reading in language education. New York: Palgrave McMillan. 